\title{
HOW TO STILL RECOGNIZE THE PERIODIC TABLE OF ELEMENTS: THE PROPOSALS OF DIDACTIC AND METHODOLOGICAL PLANNING
}

\author{
Darinka Sikošek \\ University of Maribor, Slovenia
}

\begin{abstract}
The methodical approach presents the proposals of didactic-methodological planning of curriculum password "Fields in the periodic system" for the needs of the key components of teaching \& learning process. The didactic-methodological proposal of each of the current macro-didactic components of the learning process includes the following didactic elements: chemical terms, method / method's password, didactic tool, didactic material.

For each macro-didactic component, it is planned to use one of the methods from the author's "methodic hexaplet", defined by the didactic formula ADDGPS: Analogy-Drama-Dance-GamePantomime-Socratic dialogue. The dance method is used to acquire the concepts of atomic orbitals and electronic configurations of the elements. The macro-component repeating involves the roleplay method used to implement the Expeditionary Visit of PTE by using the Identity card of the element. Both methods of quiz conversation method according to Socrates and the Small PTE cells are used for evaluation.

The use of all the mentioned methods is evaluated in terms of the competencies that must be mastered by the teacher, as well as the competencies that the student acquires when performing an individual method.
\end{abstract}

Keywords: Periodic table of elements; chemical terms; ADDGPS methods (Analogy-Drama-DanceGame-Pantomime-Socratic dialogue)

\section{Introduction}

Introduction highlights of some key facts about the periodic table of elements. The year 2019 comprises two anniversaries, namely, the 150th anniversary of the discovery of the Periodic Table of the Elements (PTE), as well as the 230th anniversary of one of more previous forms of PTE (especially the classification of A. Lavosier, who arranged the 33 elements, well-known in his period, this device (learning and including research), that is still a key source of information about the chemical elements today. To commemorate these discoveries, 2019 was proclaimed by many organizations ${ }^{1}$ as The International Year of the Periodic Table of Chemical Elements (IYPT) 2019 (The International Year of the Periodic Table, 2019).

At the beginning, we remember our school knowledge of the structure of the PTE as an organized table of all known elements (118), known so far (Anderluh et al., 2019; Turel, 2019), arranged by the order number (Z) of the element. The PTE table consists of seven horizontal rows, designated as periods (1-7). Element atoms of the same period have external electrons in the same shell. The periods are divided into vertical columns called groups, namely I-VIII according to the old IUPAC as well as the Chemical Abstract Service (CAS) system and 1-18 as indicated by the modern IUPAC system after 1990.

1 United Nations (UN), International Union of Pure and Applied Chemistry (IUPAC), European Chemical Society (EuChemS), International Union of Pure and Applied Physics (IUPAP), International Council for Science (ICSU), International Union of History and Philosophy of Science (IUHPS), International Astronomical Union (IAU). 
These eight groups are further divided into subgroups A and B. These letters are used (with the exception of the first two groups IA, IIA) in both systems differently. Thus, the old IUPAC system has its own labelling A and B for the groups on the left and the right of the PTE, while the A letter on the CAS system belongs to the main group elements and the letter B to the transition elements. By using simple serial numbering groups from left to right in the standard periodic table of elements, however valid, the new IUPAC scheme eliminates already mentioned muddy labelling groups.

The element atoms of the same group have the same number of electrons in the outer shell and similar properties consequently. The elements within the sub-groups have very similar properties (the latter is therefore periodically repeated), while the similarity between the two subgroups of elements is smaller. The adjective "periodic" in the description of the system of chemical elements also originates from this phenomenon (Abram et al., 1976; Beardsley et al., 1985; Drofenik, 1999).

Groups from IA to VIIA (regarding to old IUPAC numbering) are representative (main) elements. As regards the properties of the elements, separation of the elements into metals (the left side and the middle of the PTE) and non-metals (the right side of the PTE) is established. A special area of metals is the so-called transition metals, which are distinguished by their variable valence and the characteristic properties of these elements (Abram et al., 1976; Beardsley et al., 1985). The diagonal (zigzag line) drawn through the groups, separates pronounced metals (at the lower left end of the table) from the pronounced non-metals (at the top right of the PTE). On the right side of the dividing diagonal are the elements with the most pronounced intermediate properties. They are the so-called semimetals (B, Si, Ge, As, Sb, Te, Po), which are electrical semiconductors; their oxides are amphoteric (Beardsley et al., 1985; Drofenik, 1999).

Some of the PTE groups mentioned above have special names: Group 1 (IA by the old IUPAC and CAS numbering) is called the alkali (arab._al-qalya) metals (Alkali metals, 2019). Group 2 (IIA by the old IUPAC and CAS numbering) the alkaline earth metals (Alkaline earth metal, 2019), Group 17 (VIIB by the old IUPAC or VIIA by CAS) the halogens (Halogen, 2019), Group 16 (VIB by the old IUPAC or VIIA by CAS) the chalcogens (Chalcogen, 2019) and Group18 (0 by the old IUPAC or VIIIA by the CAS) the noble gases_(Noble gas, 2019). Special names have also been established for the two periods, namely the transition metals of the 6th period are called the lanthanides (after lanthan as an initial element of this species) (Lanthanide, 2019) whereas after the initial Actinium, transitional elements are named 7th periods - the actinoids (formerly the actinides) (Actinide, 2019).

\section{Methodology Applied in the Presentation of Curriculum Unit "Fields in the Periodic System of Elements"}

The methodical approach presents the proposals of didactic-methodological planning of curriculum unit "Fields in the periodic system" for the needs of the key components of teaching \& learning process.

Let's now, respond to the Elemental Dwarf, which calls out: Join me all (you, you and them), on my journey to the neighborhood, called the PTE, the home to as many as 118 chemical elements today (Figure 1). Taking into account the principles of greater visibility and activity, as well as individualization and socialization implemented in current process competences, we will use a tool called the Periodic Table of Elements in Cubes 
(PTEC, Figure 2) (Golob, 1986, In this journey of PTEC we can learn this and that about this and that element, and we need to find ourselves in such and other roles, which are offered by a wide range of planned didactic approaches, enriched with some methodical situations, defined in this author's ADDGPS method hexaplet (Analogy-Drama-DanceGame-Pantomime-Socratic dialogue).

\section{Figure 1}

The Periodic Table of Elements (PTE) (Anderluh et al., 2018)

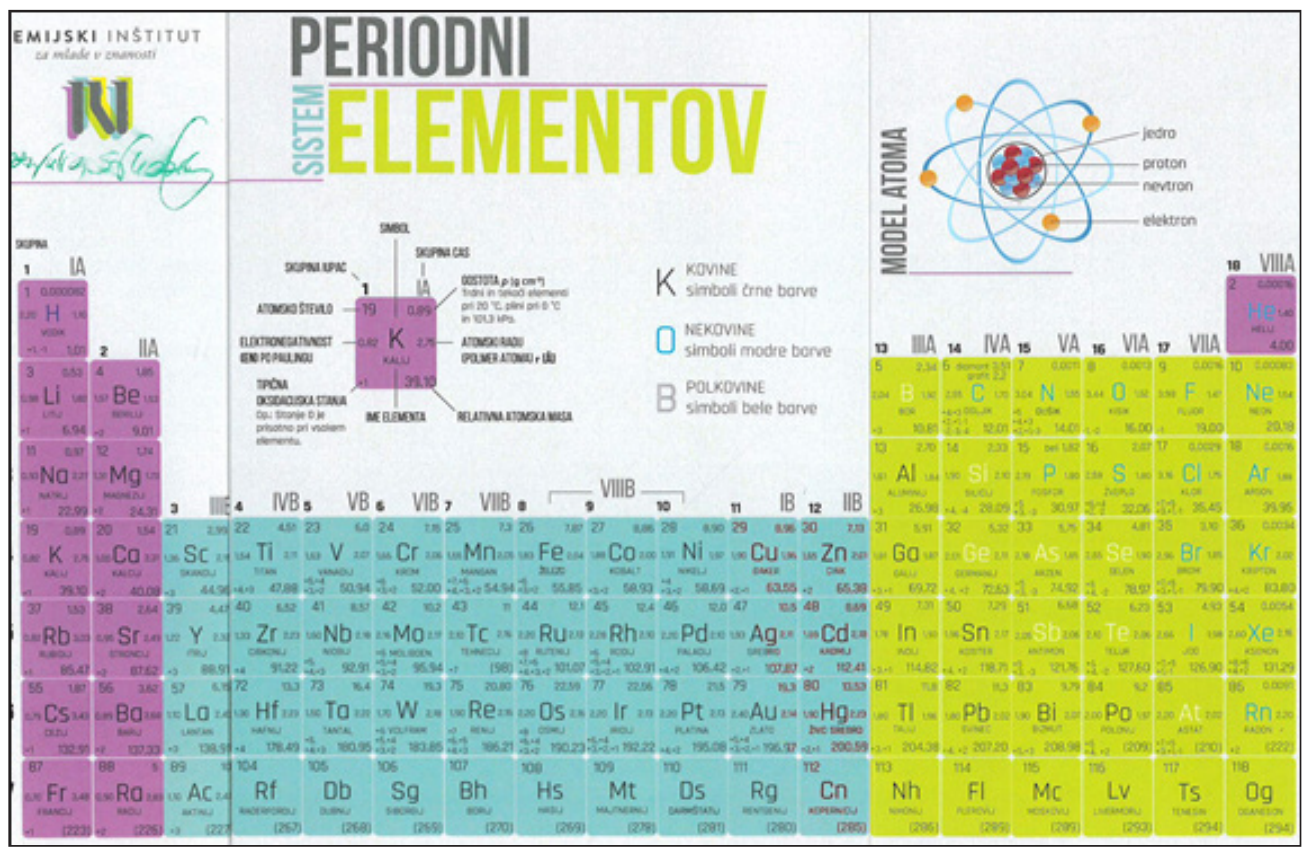

\section{Figure 2}

The Periodic Table of Elements in Cubes (PTEC)

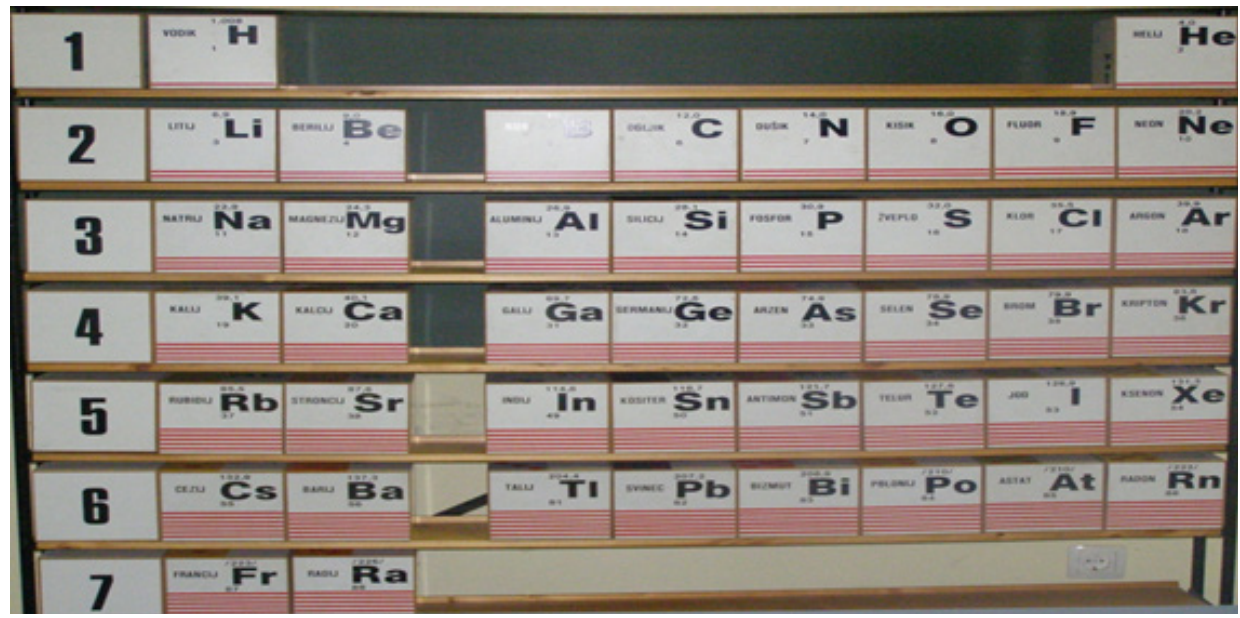

Note: (Golob, 1986; photo D. Sikošek) 


\section{Conceptual Layout and Planning of Chosen Didactic Password}

Let start so-called PTE hike within the curriculum unit "Fields in the periodic system of elements " and acquire knowledge about the location "dwelling" electrons in the atoms of certain elements. Conceptual layout and planning_of curriculum unit for the need of active acquisition with continuous consolidation of knowledge (Ac\&conCons) is shown below from Proposal 1, supplemented by Figures 1 and 2 .

Proposal 1: Didactic - Methodological planning of selected curricular unit for active acquisition with continuous consolidation (Ac\&conCons) of knowledge

Curriculum unit/ Term List: "Fields in the periodic system of elements" (Bačnik, 2008)

$\checkmark$ The distribution of the electrons in the atom

$\checkmark$ Orbitals: Quantum numbers (principal, lateral, magnetic, spin) \& energy levels

$\checkmark$ Electronic configuration (shell $\rightarrow$ period, number of external electrons $\left(\mathrm{e}^{-} \rightarrow\right.$ groups; periodicity of properties (chemical, physical) / period, group;

\section{Method / method's role // didactic tool}

Video method (Vm) \& heuristic conversation (heuConv)

$\checkmark$ ADDGPS method hexaplet (Sikošek, 1997) - expressive dance / $\boldsymbol{e}^{- \text {Orbital dances // }}$

Orbital costumes (18x; colours / blue, red, yellow; size / energy classes (1- 4); learning props ( $2 \mathrm{x}$ tennis balls, Didactic leaflets, Drama proposal);

\section{Didactic form / Work strategy of expressive dancers}

Individualized teamwork (ITW): wear "orbital costumes" $\rightarrow$ form (subdivide) the (sub) shell / atom of a single element, e.g. Si;

\section{Figure 3}

Learner' Costume Illustration of Atomic Orbitals (T-shirts) (Fišer \& Sikošek, 1999)

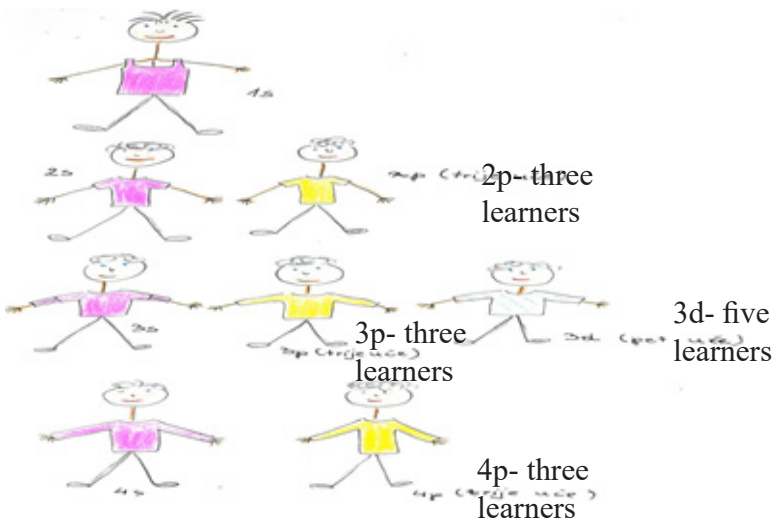

Legend:

$\Sigma$ orbital learners $=18$

$1 \mathrm{x} 1 \mathrm{~s}$

1x $2 \mathrm{~s}, 3 \times 2 \mathrm{p}$

1x $3 \mathrm{~s}, 3 \mathrm{x} 3 \mathrm{p}, 5 \mathrm{x} 3 \mathrm{~d}$

1x 4s, 3x 4p

$2 \mathrm{p}, 3 \mathrm{p}, 4 \mathrm{p} \rightarrow$

$3 \mathrm{x}$ - three learners

$3 \mathrm{~d} \rightarrow$

$1 \mathrm{x}$ - five learners 
Since it will be necessary to hurry up after the escaped element with the symbol Si (silicon), let's start now by collecting information to produce his identity (ID) card. Therefore, we immediately search for the necessary information and write it down to ID card of each element which comprises the data (Bugarin \& Sikošek, 1997), set out below.

\section{Element's Identity Card}

Name/Symbol:
Position of the element in the periodic
table:
Atomic number:
Mass number:
Number of external e-:
Number of electron shells:
Electronic configuration:

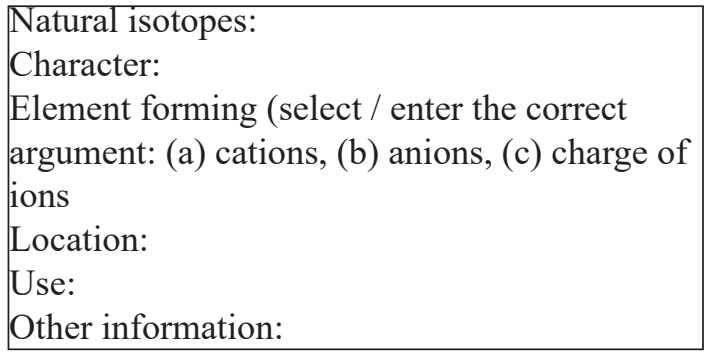

Note: The necessary information about a given element is written in a symbolic form on the individual cube PTEC (Golob, 1986). For reading these we use the legend represented by table 1.

\section{Table 1}

The Legend of the Tags on the Surface of the Cube of PTEC Learning Tool

\begin{tabular}{|c|c|}
\hline Tags & Information \\
\hline All & $\checkmark$ element name \& symbol, $\checkmark$ atomic \& mass number \\
\hline 1 horizontal lines & $\checkmark$ red, illustrate shell numbers $=$ period number \\
\hline 2 colored ribbons & $\begin{array}{l}\checkmark \text { vertical } \rightarrow \text { the direction of the group, } \checkmark \text { same color } \rightarrow \text { some } \\
\text { common properties of the group; } \checkmark \text { number }{ }_{\text {outer }} \mathrm{e}^{-} / \text {ribbon }= \\
\text { group number }\end{array}$ \\
\hline 3 circles / color, scale & $\checkmark$ atom (black), $\checkmark$ ion (red, charge) \\
\hline 4 color triangle (position / PTEC) & $\begin{array}{l}\checkmark \text { metals (black), } \checkmark \text { non-metals (red), } \checkmark \text { half-metals (black \& } \\
\quad \text { red) }\end{array}$ \\
\hline 5 location & $\begin{array}{l}\checkmark \text { lithosphere (brown), } \checkmark \text { hydrosphere (dark blue), } \\
\checkmark \text { biosphere (green), } \checkmark \text { atmosphere (light blue) }\end{array}$ \\
\hline 6 use (sign) & $\begin{array}{l}\checkmark \text { industry (factory), } \checkmark \text { energy (red, arrow), } \checkmark \text { life (green leaf), } \\
\quad \text { radioactivity }\end{array}$ \\
\hline
\end{tabular}

Since the concepts of orbitals and electronic configuration (as key concepts) of silicon homes in the PTEC hamlet have already been acquired, now let's put our best foot foremost and follow the call of Elemental Dwarf, who calls us from one of the hamlets in the PTE already (Figure 4). Now it is necessary to identify the student who embodies the Si element with his / her ID card. Let's help his / her electronic companions wear orbital costumes and go with them on a hike, called the "Expeditionary Hike PTE (PTEC)" (Figure 4). 


\section{Figure 4}

Learners' Illustration the Electronic Configuration of Si Atom (Fišer \& Sikošek, 1999)

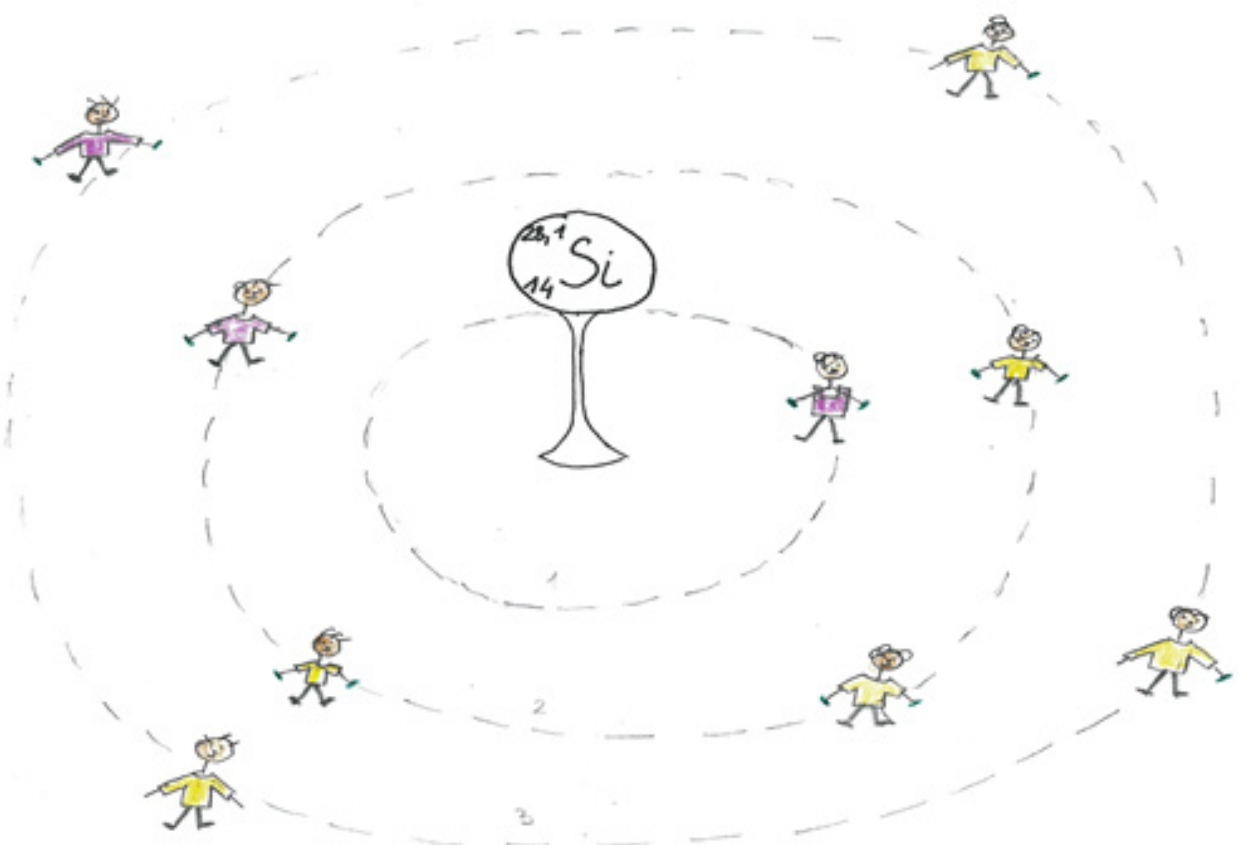

Note: The formal record of the electronic configuration of Si atom: $1 \mathrm{~s}^{2} 2 \mathrm{~s}^{2} 2 \mathrm{p}^{6} 3 \mathrm{~s}^{2} 3 \mathrm{p}^{2}$

Legend: $\checkmark$ different coloured shirts as types of orbitals: s, p, d; $\checkmark$ props (e.g. ball) in hand like an electron.

For the needs of the teacher's planning the implementation of the teaching \& learning situation called repetition (R) for the methodical password "Expeditionary Hike PTE (PTEC)" is enclosed with reduced didactic-methodological proposal (DMP) - see Proposal 2. 


\section{Proposal 2: Didactic - Methodological planning of the actual learning unit for active repeating $(\mathbf{R})$}

\section{Learning unit/ Term List: Atomic Structure and Periodic Table (Bačnik, 2008)}

$\checkmark$ Element: name, position in PTE, order number, mass number, No. out. e-, elec. configuration, ion (charge) - cation, anion, character (non-, semi-) metal, location, use; $\checkmark$ The position of the element in the PTE: group, period, No. shells, No. out. $\mathrm{e}^{-}$, metals, non-metals, semi-metals.

\section{Method / method's role // didactic tool}

ADDGPS method hexaplet - Role Play i.e. PTEC Expeditionary Hike // "Si Elemental ID card" // learning tool PTEC (Physical) \& Legend of cube's tags Note: The Si element is only selected as a sample example; the teacher should also identify examples of other elements.

\section{Didactic Form / Strategy works of expeditionary hikers}

ITW: When using PTEC, complete the didactic material "ID card of the element Si": on the cube of this element, students recognize the necessary data and thus fill in its dispatch, i.e. ID card.

Note: For an expanded set of elements, the IDs of other elements must also be completed.

Each team member determines the location of the previously recognized "escaped element" from the PTEC.

Previously acquired and now repeated knowledge is followed by testing $(\mathrm{T})$ and assessing (As) this knowledge as the usual final macrodidactic component (MDC) of the learning process. Therefore, the following is a shortened DMP (Proposal 3) for the method's role "Socrates' Quiz"(Fišer \& Sikošek, 1999; Flisar \& Sikošek, 2000; Socrates, 2019), i.e. a dialogue method in the form of Socrates' (teacher's) questions and learners answers (Šimenc, 2019). 


\section{Proposal 3: Didactic - Methodological planning of learning unit for active $T \&$ As of knowledge}

Learning unit / Glossary (Bačnik, 2008): Periodic Table of the Elements (PTE)

Orbital: energy levels $\leftrightarrow$ quantum numbers: main (shells), side (sub-shells)

$\checkmark$ Position of a given element in PTE: electronic configuration (shell $\leftrightarrow$ period, number of outer e- $\bullet$ group; periodicity of properties (chemical, physical) / period, group;

Element Sharing:

(a) Groups: • main (metals, semi-metals, non-metals), $\bullet$ sides (transition elements);

(b) Metals - properties: • physical (durability, conductivity, fineness, ...), $\bullet$ chemical (basic oxides, reducing agents, cations);

(c) Non-metals - properties of: • physical (insulators, fragility,...), • chemical (acidic oxides, oxidants, anions);

$\checkmark$ Element properties: s-, p-, d-, f- block elements $\rightarrow$ common properties / single / block $\leftrightarrow$ change of properties by PTE, element recognition (identifying) / given properties.

\section{Method / method's role// didactic tool}

Method hexaplet ADDGPS - quiz conversation, implemented in two versions :

(a) PTE Quiz a' la Socratic Dialogue (Flisar \& Sikošek, 2000; Socrates, 2019 or

(b) Small PTE Cells (Flisar \& Sikošek, 2019) // Quiz (Leaf \& Field \& Rules);

Cognitive Category (CC) of Quiz Questions / Tasks $\leftrightarrow$ Specification Table: CC 1-3 (green), CC 4 (red), CC 5-6 (blue) // Criteria List (CL).

\section{Didactic form (of work) // Work strategy}

Individual (I) work for the above method (a) where the following work strategy is implemented using Socrates' questionnaires: Gradual selection of questions \& tasks at different cognitive levels (three color quiz boxes) $\leftrightarrow$ Question answering \& Solving quiz tasks $\rightarrow$ Submission of quiz slips $\leftrightarrow$ Listening to Socrates' (i.e. teacher's) feedback \& giving learners' responses to these feedbacks.

Heterogeneous ITW for the above method (b) using the following work strategy:

$\checkmark$ Order of response, $\checkmark$ The selection (choice) of Quiz task (done by one group learner) $\rightarrow$ Group consultation response; $\checkmark 3$ member Commission - work strategy (course of play) $\rightarrow$ evaluation (assessment) of response (scoring); $\checkmark$ Potential replying of a preregistered group (in case of the incorrect answers); $\checkmark$ Winning group (the one with the highest score); $\checkmark$ Teacher's supervisory role. 
Proposal 4 (shown as a Poster 1, only excerpt): Quiz Sheet Box for MDC of T\& As Examples of tasks for evaluation by CC (Fišer \& Sikošek, 1999; Flisar \& Sikošek, 2000)

Learning unit / Glossary (Bačnik, 2008): Periodic Table of the Elements (PTE)

$$
\text { CC } \Rightarrow \text { 1-3, Sample task } 1
$$

Quiz sheet 1 (atom particles)

$\checkmark$ Specifies the number of particles in atom of phosphorous! (use PTE!)

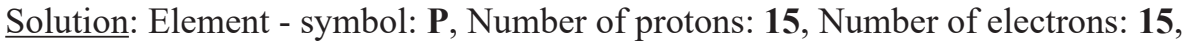
Number of neutrons:16

\section{$\mathrm{CC} \Rightarrow 4$, Sample task 1}

Quiz sheet 1 (physical \& chemical properties, chemical bond)

\section{P Identify which statement does not apply to the following elements:}

a) The atomic radius of Group I elements increases in the $\mathrm{Li} \AA \mathrm{K}$ direction.

b) The strongest oxidant in the second period is fluorine.

c) The ability to receive $\mathrm{e}^{-}$in the third period drops in the direction of sodium ${ }^{\circledR}$ chlorine.

d) The elements of Group 7 are mutually merging.

e) Potassium and oxygen are bound by ion bond.

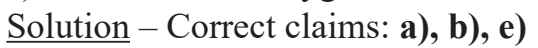

\section{$\mathrm{CC} \Rightarrow \mathbf{5 - 6}$, Sample task 1}

Quiz sheet 1 (chemical properties, chemical bond, terms regarding the number of basic particles of the atomic nucleus)

\section{$\checkmark$ Recognize the given element from the written properties:}

a) is very reactive (explosive)

b) the oxide is basic

c) forms ionic compounds (one of which is considered the most delicious)

d) is a soft silver-white metal

e) has reduction properties

f) its electrons are arranged in three shells.

Solution: sodium (Na)

$\checkmark$ Starting from the symbol of the above identified element and applying the periodic table of the elements explains the equation: $A=Z+N$

Solution: Na: $23=11+12$

mass number (A), i.e. sum of protons and neutrons $=$ order (atomic) number i.e. (protons) $(\mathrm{Z})+$ number neutrons $(\mathrm{N})$ 
The selected Term - Electronic Configuration: Examples of CC Tasks (Fišer \& Sikošek, 1999; Flisar \& Sikošek, 2000)

Understanding \& Application:

$\checkmark$ Record the electronic configuration for P!

Solution: Element P: $1 \mathbf{s}^{2} 2 \mathrm{~s}^{2} 2 \mathbf{p}^{6} 3 \mathrm{~s}^{2} 3 \mathrm{p}^{3}$

Analysis \& Evaluation:

$\checkmark$ Which element is the electronic distribution of A and B respectively?

Didactic Material 3: cont.
A: $1 \downarrow \uparrow 2 \downarrow \uparrow \downarrow \uparrow \downarrow \uparrow \uparrow$
Element $\mathrm{A}=\mathbf{F}$
$\mathrm{B}: 1 \downarrow \uparrow 2 \downarrow \uparrow \downarrow \uparrow \downarrow \uparrow \downarrow \uparrow 3 \uparrow$
Solution:
Element $\mathrm{B}=\mathbf{N a}$

$\checkmark$ Compare the distributions of electrons $\left(\mathrm{e}^{-}\right)$by orbitals in the atoms of elements labelled $\mathrm{M}, \mathrm{N}, \mathrm{O}, \mathrm{P}$ and make the correct claims:

M: $1 s^{2} 2 s^{2} 2 p^{6}$

$\mathrm{N}: 1 \mathrm{~s}^{2} 2 \mathrm{~s}^{2} 2 \mathrm{p}^{1}$

O: $1 \mathrm{~s}^{2} 2 \mathrm{~s}^{2} 2 \mathrm{p}^{6} 3 \mathrm{~s}^{1}$

P: $1 s^{2} 2 s^{2} 2 p^{6} 3 s^{2}$

$\checkmark$ Which claims about elements $M, N, O$ and $P$ are correct?

a) Element $\mathrm{N}$ lies in the Group 2 of PTE.

b) Element $\mathrm{M}$ is a non-reactive gas.

c) Element $\mathrm{P}$ is in the Group 2 of PTE.

d) Atoms element $\mathrm{O}$ easiest to submission $1 \mathrm{e}^{-}$

Correct solutions: b), c), d);

Synthesis \& Evaluation:

$\checkmark$ Write down the symbol and the electronic configuration of the element, based on its location:

Group 7, Period 4!

Solution: Element Br: $1 s^{2} 2 s^{2} 2 p^{6} 3 s^{2} 3 p^{6} 3 d^{10} 4 s^{2} 4 p^{5}$

Implementing instructions for the course of the Quiz à la Socratic dialogue (Fišer \& Sikošek, 1999)

(1) Teacher and learners co-create of a supervisory group (teacher remains "Primus per partes!');

(2) Learners create the tandem groups;

(3) Democratic (consensual) creation of quiz order (items: task selection, order of response, mutual consultative response, involvement of members of other groups in the case of a wrong answer (wrong solution of the task), status of the winner; 
(4) A collaborative definition of the work of the supervisory group (especially student and teacher work);

(5) Point evaluation of the quality of answers and solutions.

\section{Didactical Considerations}

In the discussion we can outline the competencies related to the active learning methods used, required from teachers as well as those are obtained for students. Previously presented suggestions of didactic-methodological planning of the macro-components of the didactic process from initial acquisition through continuous consolidation and through repetition with final assessment by evaluating the curricular knowledge of the periodic system of elements emphasize the methods, used for active teacher teaching and learners' learning. Therefore, we now dedicate the final word to the evaluation of "methodical" competences, namely those needed by the teacher (as a didactic) as well as those acquired by the learners (read: acquire $\&$ reinforce and repeat as well as self-evaluate). Evaluating the extent and quality of the learner's acquired competences is an expected teacher's assignment, but at the same time, the learners' desires (whether planned or spontaneous) are realized in this didactic situation.

Let us now summarize the main conclusions of active teaching and learning for the learning unit "Periodic Table of Elements", where the use of some methods is realized from ADDGPS method hexaplet. The following is an orderly record of the competency evaluation of the demonstrated teachers' and learners' acquired curricular knowledge, skills and attitudes required by the methods used during the implementation of a regular MDC.

\section{Summary Record}

Competent evaluation of methods used in teaching \& learning the learning unit "Periodic Table of Elements" follows in advance.

Competent evaluation of the orbital dance method (used in Ac \& conCons)

Teacher's required competencies (Preksavec, 2015; Todorović, 2018)

$\checkmark$ "Competence" verbs: to know, to master, to provide, to direct, to participate, to use, to possess and so on;

$\checkmark$ Identified key teacher competencies - he/she:

(1) knows how to choose and apply different teaching strategies and methodical procedures in teaching;

(2) mastered theoretical and movement knowledge (e.g. rhythm, tempo, dynamics, simple dance choreographies, e.g. rotation, mimicking the appearance of objects);

(3) provides relevant feedback to learners;

(4) directs and masks inter-subject linking, e.g. chemistry and... e.g. sports, music;

(5) knows how to design and use the necessary work aids and didactic materials;

(6) participates in teamwork (either with a physical education teacher or a dance teacher);

(7) has a sense of aesthetics and creative ability of creation (for example: music selection ...). 
Learners acquired competences (Preksavec, 2015; Todorović, 2018):

$\checkmark$ Competence verbs: to assert, to design, to develop, to encourage, to experience, to express, to execute, to enforce, to present and so on;

$\checkmark$ Identified key learner competencies - they:

(1) develop movement PTE conceptual concentrations;

(2) develop social competencies (especially mutual cooperation, understanding);

(3) experiencing understood abstract concepts curriculum password PTE as an incentive for learning chemistry;

\section{Competent evaluation of PTEC expeditionary hike as a role-playing method} (used in $\boldsymbol{R}$ )

Teacher's required competencies (Sikošek, 1997; Jerina, 2011)

$\checkmark$ "Competence verbs": to act in a role, to be able, to stimulate, to be able to understand, to define and the like;

$\checkmark$ Identified key teacher competencies - he/she:

(1) acts as a partner and facilitator;

(2) is able to adapt flexibly to the unpredictability of the learning situation;

(3) encourages learners to explain, justify, draw conclusions and make predictions;

(4) understands the resulting shortcomings (arising from the course of the learning situation) and defines the necessary actions.

Learners' acquired competences (Sikošek, 2011)

$\checkmark$ "Competency verbs": to repeat, to acquire, to takeover $\&$ to develop, to get used to, to take into account and the like;

$\checkmark$ Identified key learners' competencies - they:

(1) repeat the already acquired knowledge (basic concepts and important knowledge about PTE);

(2) in a more relaxed atmosphere (such as virtual walkers PTE) they gain more rewarding educational experience;

(3) in the role of hikers take personal responsibility in carrying out the joint task of the expedition as a professional hike and, as a result, develop their own learning confidence; (4) are as the hikers successful in cooperative learning taking into account the knowledge of other members of the expedition.

Competent evaluation of conversation methods PTE quiz a'la Socratic and Small PTE cells (used in $\boldsymbol{T} \& \boldsymbol{A s}$ );

Teacher's required competencies (Sikošek, 1997; Fišer \& Sikošek, 1999; Flisar \& Sikošek, 2000):

$\checkmark$ "Competency verbs": to give, to coordinate, to select and so on; 
$\checkmark$ Identified key teacher competencies - he/she:

(1) gives instructions (organizational, executive...); (2) coordinates the conduct of the verification \& assessment work; (3) selects members of the supervisory group.

Learners acquired competences (Fišer \& Sikošek, 1999; Flisar \& Sikošek, 2000; Krajnc, 2017):

$\checkmark$ "Competence" verbs: to answer, to conclude, to identify and comment on, to evaluate, to co-design and comply with and the like;

$\checkmark$ Identified key learners' competencies - they:

(1) answering the questions; (2) conclude possible answers or solutions, (3) identify and comment on the correctness of the questions answered and the tasks accomplished, which in turn leads to a better substantive understanding; (4) evaluate the answers (using a point key), (5) co-design and follow the implementing rules of the Socratic Quiz.

\section{Summing up}

Some outlined recommendations regarding the use of previously competently evaluated active methods are outlined in this summing up. Certainly, the teachers of didactics as well as experienced teachers of chemistry we are the only ones in the knowledge that the planned methods of the performed macro-didactic situations of teaching and learning of the curricular password "Periodic Table of Elements" enable the realization of the defined competences of the teacher and the learners.

Both bearers of the learning process are working in partnership in accordance with Delphi's saying "Know thyself! This cognition leads the learner to an understanding of knowledge, which as such becomes useful, and, consequently, more permanent. Let Socratic dialogue (as a method of asking open questions to encourage them to consider) become the choice of the teacher in guiding learners to discover the curricular knowledge of PTE. Among the competences of the learner as a co-bearer of the Socratic dialogue, we can especially emphasize his acquired ability to argue about his own thinking, as well as to show his listening to the thinking of classmates. Of course, this competence in general also leads to a critical assessment of students' current knowledge, which in this case is knowledge of the laws of PTE.

However, author would like to emphasize a few: the didactic-methodological approaches presented here were also used, tested and empirically evaluated in the direct training of our future chemistry teachers otherwise only by feedback from the student teacher and his/her colleagues as active observers and especially with deeper methodic analysis by the teacher of didactic of chemistry.

Of course, every chemistry teacher knows that to the goal - How to reach the learner's understanding of the hidden knowledge of the periodic table of elements as an indispensable source of basic information? - lead different methodological paths. The author recommends the use of Socratic dialogue as a method of teaching and learning because it helps to break the umbilical cord, which connects the student with the teacher (as the authority) and thus mentally makes him independent. This presentation should conclude with the author's confidence in a competently qualified teacher, so that he or she will never be embarrassed in choosing a student-centered path. For, only such a learning 
path can lead his / her students to understand the periodic table of elements as the heart of all chemical sciences.

\section{Acknowledgement}

In acknowledgment or my word of thanks, I turn myself to those who have enabled me to do so. The author's first thanks go to the Slovenian Chemical Society, which enabled me to express myself orally at the $25^{\text {th }}$ Annual Meeting of the Slovenian Chemical Society (this was a conference called "Slovenian Chemical Days", which took place in September 2019 in Maribor). In honor of last year's 150th anniversary of The periodic Table of the Elements, I decided (as a teacher of didactics of chemistry) that just mentioned oral presentation now complemented by the article and also shed light on innovative didacticmethodological approach, which was developed jointly with my former students - teachers of chemistry .

So, my other thanks go to my former students - teachers, with whom we have consistently realized the varied challenges of actively teaching and learning the basic of chemistry where something is constantly going on.

\section{References}

Abram, V., Dolar-Bergant, J., Duhovnik, J., Kregar, M., Likar, P., Schaue, M.,...\& Spanring, J. (1976). Kemija [Chemistry]. In: K. Dolinar (Ed.). Leksikoni Cankarjeve založbe (pp. 189190). Cankarjeva založba.

Actinide (August 19, 2019). In: Wikipedia. https://en.wikipedia.org/wiki/Actinide

Alkali metals (August 19, 2019). In: Wikipedia. https://en.wikipedia.org/wiki/Alkali_metal

Alkaline earth metal (August 19, 2019). In: Wikipedia. https://en.wikipedia.org/wiki/Alkaline_ earth_metal

Anderluh, G., Jeran, M., Kastelic, M., Mali, G., Petek, U., \& Šala, M. (2018). Periodni system elementov (zgibanka) [Periodic table of elements] (Leaflet). Kemijski inštitut za mlade $\mathrm{v}$ znanosti, Kemijski institut Ljubljana.

Bačnik, A. (2008). Učni načrt. Kemija.[Curriculum. Chemistry]. URN:NBN:SI:doc-HSULNRLP (August 17, 2019). http://www.dlib.si

Bugarin, B., \& Sikošek, D. (1997). Pisna priprava na učno enoto: Zgradba atoma in periodni sistem [Written preparation for teaching unit: Atomic structure and periodic system]. (Internal material, unpublished). Oddelek za kemijo, Pedagoška fakulteta Maribor.

Chalcogen (August 19, 2019). In: Wikipedia. https://en.wikipedia.org/wiki/Chalcogen

Drofenik, M. (1999). Zbrana gradiva iz splošne in anorganske kemije [Collected materials from general and inorganic chemistry] (pp. 23-24). Maribor: Fakulteta za kemijo in kemijsko tehnologijo.

Fišer, N., \& Sikošek, D. (1999). Področja v periodnem sistemu: Elektronska konfiguracija atomov elementov, Razvrščanje elementov v PS, Značilnosti elementov [Areas in the Periodic Table: Electronic configuration of element atoms, sorting elements in PS, element features]. (Internal study material, unpublished). In: Didaktika kemije. Oddelek za kemijo, Pedagoška fakulteta Maribor.

Flisar, L., \& Sikošek, D. (2000). Didaktične enote z uporabo metod aktivnega učenja [Didactic units using active learning methods]. (Internal study material, unpublished). In: Didaktika kemije. Oddelek za kemijo, Pedagoška fakulteta, Maribor.

Golob, M. (1986). Periodni sistem elementov v kockah - učilo [Periodic system of elements in cubes - teaching aid]. A \& A podjetje za proizvodnjo, marketing in inženiring, Domžale.

Halogen (August 19, 2019). In: Wikipedia. https://en.wikipedia.org/wiki/Halogen 
Jerina, B. (2011). Konstruktovistične vzgojnoizobraževalne prakse [Constructovist educational practices]. (Master's thesis). Univerza v Ljubljani, Fakulteta za družbene vede. (August 3, 2019). http://dk.fdv.uni-lj.si/diplomska/pdfs/jerina-barbara.pdf

Krajnc, Ž. (2017). Platonova prispodoba o votlini in njen pomen za predšolsko pedagogiko [Plato's parable of the hollow and its importance for preschool pedagogy]. (Master's thesis, p. 14). Univerza na Primorskem, Pedagoška fakulteta Koper, Visokošolski študijski program prve stopnje predšolskega izobraževanja. (August 3, 2019). https://www.worldca.org/title/ platonova-prispodoba-o-votlini-in-njen-pomen-za-predsolsko-pedagogiko

Lanthanide (August 19, 2019). In: Wikipedia. https://en.wikipedia.org/wiki/Lanthanide

Noble gas (August 19, 2019). In: Wikipedia. https://en.wikipedia.org/wiki/Noble_gas

Periodic table (1985). In J. Daintith (Ed.), Concise dictionary of chemistry (pp. 212-13). Oxford University Press.

Preksavec, K. (2015). Ples v predšolskem obdobju [Dancing in the preschool period] (Master's thesis). Univerza v Ljubljani, Pedagoška fakulteta, Oddelek za razredni pouk, Študijski program: Predšolska vzgoja. https://pefprints.pef.uni-lj.si/2853/1/Diplomska-nalogaKatarina-Preskavec.pdf

Sikošek, D. (1997, Oktober 16-18). Z analogijo in igro do kemijskega znanja [By analogy and the game to chemical knowledge, Conference session]. 6th Meeting of Slovenian Chemistry Teachers, Kranjska gora, Slovenija. Ljubljana: In: BITEKS: Kemija v šoli. 1 f. COBISS. SI-ID - 64110166473480.

Sikošek, D. (2011). Metode sodelovalnega dela, uporabljene pri preverjanju in ocenjevanju kompetenčnih dosežkov študentov-učiteljev kemije [Collaborative work methods in evaluation and assessment of competence achievements of students - future teachers of chemistry]. Didactica Slovenica, 26(3), 53-71.

Socrates (August 1, 2019). In: Wikipedia. https://en.wikipedia.org/wiki/Socrates

Šimenc, M. (2019). Nove prakse filozofije [New Practices of Philosophy] (August 3, 2019). https://www.pef.uni-lj.si/fileadmn/Datoteke/Zalozba/e-publikacije/ Simenc_Nove-praksefilozofije.pdf

The International Year of the Periodic Table, A Common Language for Science (August 1, 2019). https://www.iypt2019.org

Todorović, K. (2018). Kompetence razrednih učiteljev za poučevanje predmeta šport [Competences of classroom teachers for teaching sports] (Master's thesis). Univerza v Mariboru, Pedagoška fakulteta, Odelek za razredni pouk). (August 3. 2019). https://dk.um.si/Dokument. php?id=126079

Turel, I. (2019). Periodni sistem elementov 150 letnik, ki je še vedno živahen [Periodic system of elements 150 year old, who is still alive]. Kemija $v$ šoli in družbi, 1, 3-4.

Received 10 November 2020; Accepted 04 December 2020

Cite as: Sikošek, D. (2020). How to still recognize the periodic table of elements: The proposals of didactic and methodological planning. Gamtamokslinis ugdymas / Natural Science Education, 17(2), 124-138. https://doi.org/10.48127/gu-nse/20.17.124

\section{$\left[\begin{array}{ll}\hline \text { Darinka Sikošek } \\ \end{array}\right.$}

$\mathrm{PhD}$, Assistant Professor, Faculty of Natural Science and Mathematics, University of Maribor, Koroška 160, 2000 Maribor, Slovenia.

E-mail: darinka.sikosek@guest.uni.si

Website: http://www.uni-mb.si 